\title{
Assessment of Water Quality and Microbial Load of Dhaleshwari River Tangail, Bangladesh
}

\author{
Md. Khalid Hassan Real', Natasha Khanam ${ }^{1}$, Md. Younus Mia ${ }^{1 *}$, Marufa Nasreen ${ }^{2}$ \\ ${ }^{1}$ Department of Environmental Science and Resource Management, Mawlana Bhashani Science and Technology University, \\ Tangail, Bangladesh \\ ${ }^{2}$ Department of Biotechnology and Genetic Engineering, Mawlana Bhashani Science and Technology University, Tangail, \\ Bangladesh \\ Email: ^mdmia1998@gmail.com
}

How to cite this paper: Real, Md.K.H., Khanam, N., Mia, Md.Y. and Nasreen, M. (2017) Assessment of Water Quality and Microbial Load of Dhaleshwari River Tangail, Bangladesh. Advances in Microbiology, 7, 523-533.

https://doi.org/10.4236/aim.2017.76041

Received: May 8, 2017

Accepted: June 23, 2017

Published: June 26, 2017

Copyright () 2017 by authors and Scientific Research Publishing Inc. This work is licensed under the Creative Commons Attribution International License (CC BY 4.0).

http://creativecommons.org/licenses/by/4.0/

c) (†) Open Access

\section{Abstract}

The present study was undertaken to investigate some water quality parameters $\left(\mathrm{pH}, \mathrm{BOD}, \mathrm{DO}\right.$ and water temperature), anion concentration $\left(\mathrm{PO}_{4}^{3-}\right.$, $\mathrm{SO}_{4}^{2-}$ and $\mathrm{NO}_{3}^{-}$) and the availability of some selected microorganisms consisted of total coliform, fecal coliform (Escherichia coli) and Vibrio cholerae in the Dhaleshwari river during the period from April to June 2015. The water samples were collected from three different stations of the river namely Belta (St-1), Kendua (St-2) and Charabari (St-3) under the Porabari union at Tangail Sadar Upazilla. Water temperature varied from $29.5^{\circ} \mathrm{C}$ in June to $31.7^{\circ} \mathrm{C}$ in May with a highest mean $31.17 \pm 0.47$ in May. The $\mathrm{pH}$ of water was slightly alkaline in nature and ranged between 7.25 in June and 8.45 in April. Mean concentrations of BOD $0.87 \pm 0.19,1.12 \pm 0.6$ and $0.97 \pm 0.67$ were recorded in April, May and June respectively. Highest $\mathrm{PO}_{4}^{2-}$ value $4.4 \mathrm{mg} / \mathrm{l}$ was found in May and lowest value of $\mathrm{PO}_{4}^{2-} 1.74 \mathrm{mg} / \mathrm{l}$ was found in June. Mean sulfate values at different months of Dhaleshwaririver were $6.61 \pm 1.78 \mathrm{mg} / \mathrm{l}, 7.61 \pm$ $2.16 \mathrm{mg} / \mathrm{l}$ and $3.68 \pm 0.23 \mathrm{mg} / \mathrm{l}$ respectively. Nitrate concentration in water samples varied from $0.51 \mathrm{mg} / \mathrm{l}$ in June to $3.66 \mathrm{mg} / \mathrm{l}$ in April. Total coliforms bacteria were found high in all water samples and values ranged from $11.05 \times$ $10^{8}-19 \times 10^{23} \mathrm{cfu} / \mathrm{ml}$. The highest load of total coliforms bacteria was recorded at St-2 in May and the lowest was at St-1 in April. The highest concentration of Escherichia coli counted in water sample was $6 \times 10^{13} \mathrm{cfu} / \mathrm{ml}$ at St-2 during June, while lowest concentration was $5 \times 10^{5} \mathrm{cfu} / \mathrm{ml}$ at St-1 during May. The highest concentration of Vibrio cholerae was $9.66 \times 10^{14} \mathrm{cfu} / \mathrm{ml}$ at St-1 during June, while lowest concentration was $4.2 \times 10^{8} \mathrm{cfu} / \mathrm{ml}$ at St-3 during April. The high number of total coliform, Escherichia coli and Vibrio cholerae indicated significant level of microbial pollution in Dhaleshwari river. The presence of pathogenic organisms may pose not only health hazards 
to the users of the river water but also poses risks for the aquatic organisms especially fish of the water bodies. So the occurrence of high bacterial load concluded that the water of Dhaleshwari river is polluted and unhygienic for drinking and even unsuitable for domestic purposes without proper treatment.

\section{Keywords}

Bacteria, Total Coliform, Escherichia coli, Vibrio cholerae

\section{Introduction}

Water pollution by harmful microorganisms is now a nationwide problem of developing countries like Bangladesh. To determine the extent of water pollution we consider different roles played by microorganism as well as presence of organic and inorganic pollutant [1]. Aquatic microorganisms occupy a key position in the trophic level by providing rich nourishment for the next higher level of aquatic life and thus human health and other animals may affect [2]. Water is unsafe for human consumption when it contains pathogenic or diseases causing microorganisms. The consumption of unhygienic drinking water and uses of unsafe water for daily purposes lead to the prevalence of diseases like diarrhea, typhoid, cholera, bacillary dysentery among the population [3]. The abundance and diversity of widely distributed microorganisms may be used as an indicator for the suitability of water [4]. Microbiological impairment of drinking, bathing, irrigation, or recreational water is commonly monitored using concentration of fecal indicator bacteria (FIB). The presence of Escherichia coli (FIB) is considered as inferential evidence of fecal pollution and commonly used to evaluate microbial water quality [5]. Cholera caused by toxigenic Vibrio cholerae is a major public health problem in developing countries, where outbreaks occur in a regular seasonal pattern and are particularly associated with poverty and poor sanitation [6].

In Bangladesh Dhaleshwari river acts as a most important distributary of the Jamuna river [7]. People surrounding the river mainly uses the water for drinking, bathing, washing, fishing and agricultural purposes. About $80 \%$ of all diseases are associated with waterborne pathogens in Bangladesh [8]. Keeping the above points into consideration, the present study was undertaken to enumerate aerobic heterotrophic, enteric and related waterborne pathogens to find out an overall microbial pollution of the Dhaleshwari river.

\section{Materials and Methods}

\subsection{Study Area}

Dhaleshwari river is the main distributary of Jamuna river and about $290 \mathrm{~km}$ long having average depth $37.19 \mathrm{~m}$ and maximum depth $80.79 \mathrm{~m}$ respectively. Dhaleshwari river starts off the Jamuna river near the north-western tip of Tan- 
gail district. Then the river is divided into two branches namely the northern branch retains the name Dhaleshwari and merges with the other branch Kaligonga river at the southern part of Manikgang district. Finally the merged flow meets the Shitalakshya river near the Narayanganj district. This combined flow goes southwards to merge into the Meghna river [9].

The climate of Tangail is characterized by the seasonal changing of the wind, comparatively dry \& mild winter and hot \& wet summer. Despite the traditional six seasons of the Bengali calendar traditionally Tangail district has four distinctive identifiable seasons in a year; the winter season (December to February), the unsettled period of pre-summer monsoon (March to May), the summer monsoon (June to September) and the retreating monsoon (October to November). The annual average temperature of Tangail district is maximum $38.33^{\circ} \mathrm{C}$ and minimum $10.13^{\circ} \mathrm{C}$. The annual rainfall is $1830 \mathrm{~mm}[10]$.

\subsection{Sample Collection}

Water samples were collected from three sampling stations of the Dhaleshwari river namely St-1 is at Belta, St-2 is at the Kendua at Porabari union and St-3 is at Charabari at Tangail Sadar Upazila (Figure 1). Each station is about 1.5 kilometers far from each other and water samples were collected from 1 meter far from the bank of the river. Water samples were collected in the morning between $7.30-8.30$ am during the month of April, May and June 2015. According to Brammer samples collected from April and May were fall in pre-monsoon (Having high temperature and high evaporation rates) season again samples collected from June were in monsoon season (High intensity of rainfall) [11]. We avoided scum and sampling depth was $15-30 \mathrm{~cm}$ below the water surface. Water samples were taken in sterilized glass bottles marking with the respective identification number and transported in an icebox with sufficient ice blocks to maintain the temperature around $4^{\circ} \mathrm{C}-6^{\circ} \mathrm{C}$.

\subsection{Microbial Analysis}

We performed spread plate techniques for total plate count of bacteria with serial dilution in respect of the identification of health hazard bacteria in water samples. Standard plate count (SPC) techniques were used for microbial load from the water samples [12]. For enumeration of different bacteria different selective media were used i.e. MacConkey agar for total coliform bacteria, EMB agar for Escherichia coli and TCBS agar for Vibrio cholera [13]. There considered as total counts of average colonies formed in the plates after incubated at $37^{\circ} \mathrm{C}$ for 48 hours.

\subsection{Physicochemical Analysis}

In situ data water temperature and DO were recorded with thermometer (mercury thermometer) and DO meter (LT Lulron DO-5509) during the sampling time. Water $\mathrm{pH}$ was recorded in the laboratory with the help of $\mathrm{pH}$ meter (Adwa, AD1000). Phosphate in water samples determined by UV-Visible Spectro- 


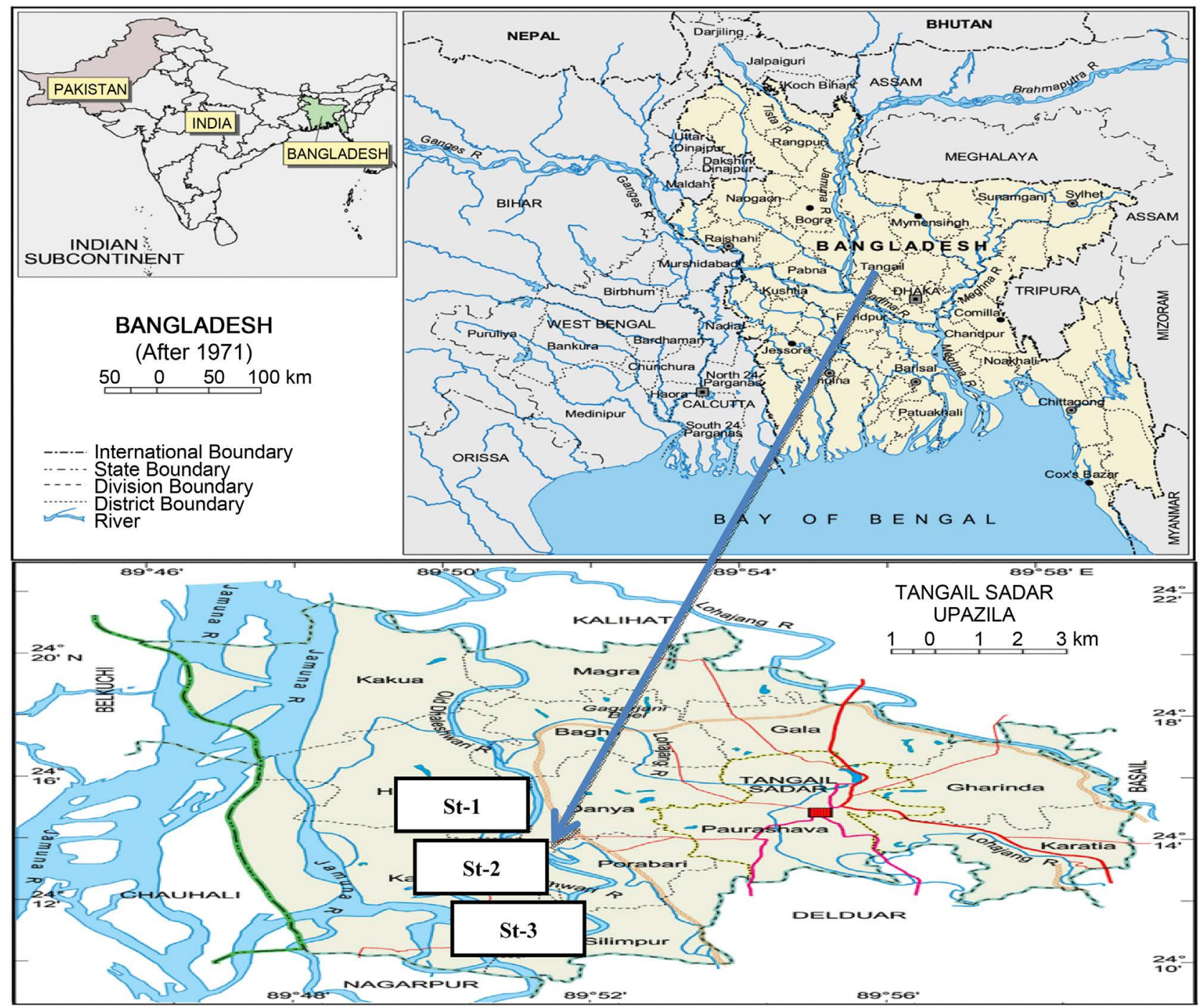

Figure 1. Map showing the study area in Dhaleshwari river at Tangail district Bangladesh [14].

photometry set by web length at $400 \mathrm{~nm}$; again $\mathrm{SO}_{4}^{2-}$ and $\mathrm{NO}_{3}^{-}$was recorded by Ion chromatography (Shimadzu Ion Chromatograph, HIC-10-A).

\subsection{Statistical Analysis}

MS Excel 2010 and SPSS 20 software were used for calculating average, standard deviation and presentation of graphs. The relation between two parameters determined by the Karl Pearson's correlation coefficient and coefficient of correlation $(r)$ determined as follows:

$$
r=r_{x y}=\frac{n \sum x_{i} y_{i}-\sum x_{i} \sum y_{i}}{\sqrt{n \sum x_{i}^{2}-\left(\sum x_{i}\right)^{2}} \sqrt{n \sum y_{i}^{2}-\left(\sum y_{i}\right)^{2}}}
$$

where $n=$ Number of samples,

$x_{i}=$ Values of $x$ variables,

$y_{i}=$ Values of $y$ variables.

For testing significance or non-significance of correlation coefficient t-test was 
used by following given formula:

$$
t=r \sqrt{\frac{n-2}{1-r^{2}}} .
$$

\section{Results and Discussion}

\subsection{Total Coliform Count}

Monthly maximum mean concentration of total coliform was recorded as $13.81 \times$ $10^{23} \mathrm{cfu} / \mathrm{ml}$ during May and minimum mean concentration of total coliform was recorded $12.7 \times 10^{8} \mathrm{cfu} / \mathrm{ml}$ during April (Figure 2). Total coliform bacteria count on MacConkey agar ranged between $0.3 \times 10^{4}$ and $3.5 \times 10^{4} \mathrm{cfu} / \mathrm{ml}$ in the Buriganga river during rainy season (July-August) [15]. Hasan et al. [16] recorded the coliform counts at several points of the Buriganga river water varied from $1.1 \times 10^{3}$ to $2.4 \times 10^{3} \mathrm{cfu} / 100 \mathrm{ml}$. Total coliform in the downstream site of the Bhusian river in Phillipines in the month of April showed the highest value of $1.7 \times 10^{13} \mathrm{cfu} / 100 \mathrm{ml}$ [17]. The causes of maximum load of total coliform bacteria in May were unhygienic conditions besides the river, less amount of water present in river, static condition of river water and the less rainfall. On the other hand there were sufficient amount of water present due to heavy rainfall and sufficient flow of river water were the causes of low bacterial load in June.

\subsection{Escherichia coli Count}

The highest concentration of Escherichia coli counted in water sample was $6 \times$ $10^{13} \mathrm{cfu} / \mathrm{ml}$ at St-2 during June while minimum concentration was found $5 \times 10^{5}$ $\mathrm{cfu} / \mathrm{ml}$ at St-1 during May (Figure 3). Monthly maximum mean concentration of Escherichia coli was recorded in June and minimum concentration of Escherichia coli was recorded in May. The higher Escherichia coli load was in June might be due to wash out of the land surface to the river by rain water as well as

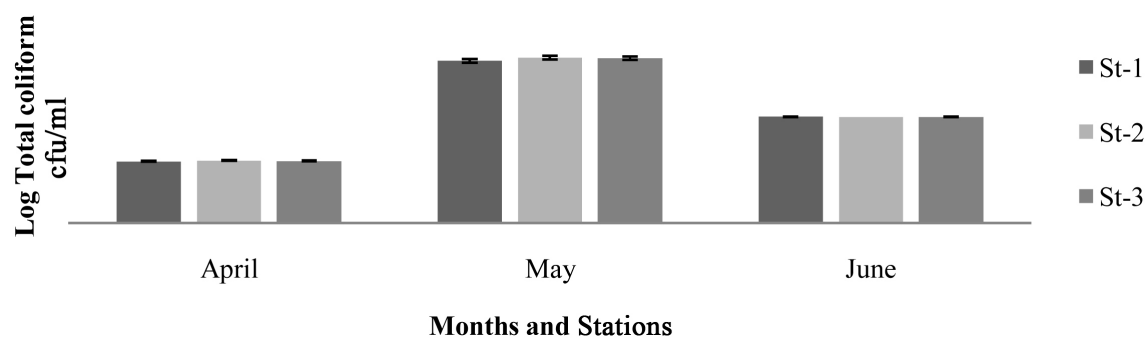

Figure 2. Total coliform bacterial load among three months in Dhaleshwari river water.

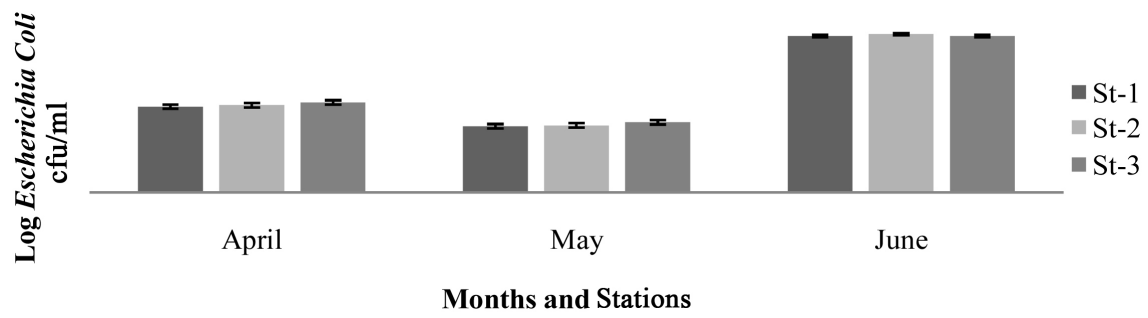

Figure 3. Bacterial load (Escherichia coli) among three months in Dhaleshwari river. 
due to the unhealthy condition of St -2 . As a result, there was the high number of Escherichia coli load in the Dhaleshwari river. In particular, E. coli is the universal indicator of fecal contamination [18]. Presence of $E$. coli, thus clearly indicated fecal pollution of the Dhaleshwari river. EPA's recommended limit of $E$. coli within recreational waters such as swimming is equal to or less than 200 cfu/100 ml [19].

\subsection{Vibrio cholerae Count}

The highest concentration of Vibrio cholerae counted in Dhaleshwari river water sample was $9.66 \times 10^{14} \mathrm{cfu} / \mathrm{ml}$ at St- 1 during June while minimum concentration was found $4.2 \times 10^{8} \mathrm{cfu} / \mathrm{ml}$ at St-3 during April (Figure 4). The highest mean concentration was recorded $6.11 \times 10^{14} \mathrm{cfu} / \mathrm{ml}$ in June and the lowest mean concentration $7.87 \times 10^{8} \mathrm{cfu} / \mathrm{ml}$ was in April. In developing countries cholera is a major public health problem which is caused by infection of the intestine with $V$. cholerae [20]. For many years cholera is an epidemic disease in Bangladesh with maintaining its regular seasonal pattern [21]. Cholera epidemics occur twice every year with the highest peak during post monsoon period (September-January) and second smaller peak during pre-monsoon (MarchMay) in Bangladesh. [22]. As Vibrio cholerae is a waterborne pathogen and the outbreak of Vibrio cholerae is highly appeared in rainy season so that it might be a cause of high load of Vibrio cholerae in June.

\subsection{Physicochemical Parameters}

In this study the lowest dissolved oxygen (DO) value $2.9 \mathrm{mg} / \mathrm{l}$ was found at St-2 in the month of May and the higher DO value $5 \mathrm{mg} / \mathrm{l}$ was at St-1 in April. Monthly mean DO value was maximum in April and the minimum mean was in May (Table 1). Islam et al. [23] found DO ranged from 4.9 to 9.0, 4.1 to 9.8 and 5.7 to $7.3 \mathrm{mg} / \mathrm{l}$ respectively in monsoon, post-monsoon and pre-monsoon seasons and the samples were collected between 9:30-11:30 am. The main causes of lower DO value in the present study were the presence of organic matter in the water body, lack of sunlight in the morning (7.30-8.30 am), nutrients from induced fertilizers, human activities and other animal wastes.

In this study highest $\mathrm{pH}$ value 8.45 was found at St-1 and St-3 in April again the lowest $\mathrm{pH}$ value 7.25 was found at St-2 in June (Table 1). Similar study was conducted by Islam et al. [23] and found $\mathrm{pH}$ value between 7.42 - 7.6, 5.0 - 6.4

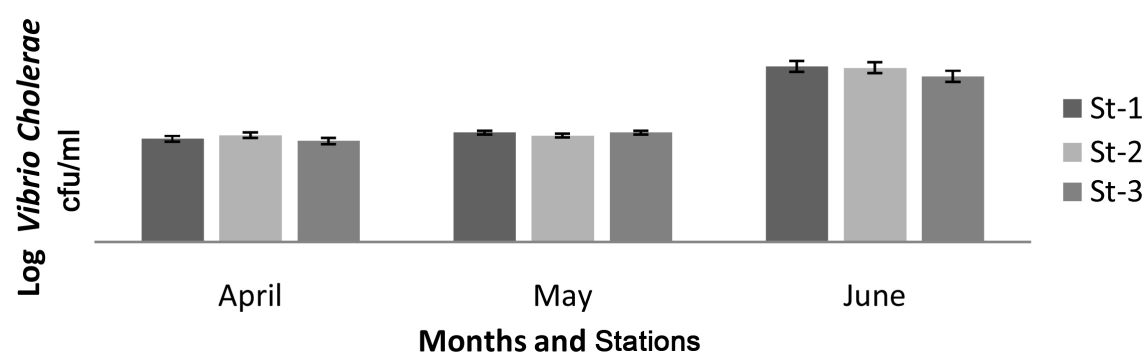

Figure 4. Bacterial load (Vibrio choleare) among three months in Dhaleshwari river. 
Table 1. Physicochemical parameters in the water samples at different stations in Dhaleshwari river.

\begin{tabular}{|c|c|c|c|c|c|c|c|c|c|}
\hline Month & $\begin{array}{c}\text { Sampling } \\
\text { stations }\end{array}$ & $\mathrm{pH}$ & Mean \pm SD & DO & Mean \pm SD & Temp & Mean \pm SD & BOD & Mean \pm SD \\
\hline \multirow{3}{*}{ April } & St-1 & 8.45 & & 4.2 & & 30.0 & & 0.71 & \\
\hline & St-2 & 8.17 & $8.36 \pm 0.16$ & 3.4 & $4.2 \pm 0.8$ & 29.9 & $29.9 \pm 0.1$ & 1.1 & $0.87 \pm 0.2$ \\
\hline & St-3 & 8.45 & & 5.0 & & 29.8 & & 0.82 & \\
\hline \multirow{3}{*}{ May } & St-1 & 7.75 & & 3.0 & & 30.8 & & 0.55 & \\
\hline & St-2 & 7.67 & $7.72 \pm 0.04$ & 2.9 & $3 \pm 0.1$ & 31.7 & $31.17 \pm 0.5$ & 1.1 & $1.12 \pm 0.6$ \\
\hline & St-3 & 7.73 & & 3.1 & & 31.0 & & 1.74 & \\
\hline \multirow{3}{*}{ June } & St-1 & 7.29 & & 3.1 & & 29.5 & & 0.65 & \\
\hline & St-2 & 7.25 & $7.28 \pm 0.03$ & 3.0 & $3.1 \pm 0.1$ & 29.6 & $29.5 \pm 0.1$ & 0.52 & $0.97 \pm 0.7$ \\
\hline & St-3 & 7.3 & & 3.2 & & 29.5 & & 1.74 & \\
\hline
\end{tabular}

and 5.4 - 5.9 respectively in monsoon, pre-monsoon and post-monsoon seasons at different stations in Dhaleshwari river. The standard value of $\mathrm{pH}$ is $6.0-8.5$ for aquatic life [24]. In the present study temperature ranged between $29.5^{\circ} \mathrm{C}$ to $31.7^{\circ} \mathrm{C}$ with mean value $29.9^{\circ} \mathrm{C} \pm 0.1^{\circ} \mathrm{C}, 31.17^{\circ} \mathrm{C} \pm 0.47^{\circ} \mathrm{C}, 29.5 \pm 0.06^{\circ} \mathrm{C}$ in April, May and June respectively.

Highest BOD value 1.74 was found at St-3 in the month of May and June and the lowest BOD value 0.52 was found at St-2 in June. Mean concentration of BOD $0.87 \pm 0.19,1.12 \pm 0.6$ and $0.97 \pm 0.67$ were recorded in April, May and June respectively (Table 1 ). Khondker and Abed recorded BOD ranged from $0.2-4.5 \mathrm{mg} / \mathrm{l}$ in the Turag river, Bangladesh [25].

\subsection{Anion Concentration at Different Sampling Stations}

Phosphate $\left(\mathrm{PO}_{4}^{3-}\right)$ concentration varied from $1.74 \mathrm{mg} / \mathrm{l}$ at St-3 in June to 4.4 $\mathrm{mg} / \mathrm{l}$ at St-2 in May. Monthly mean concentrations were recorded $3.29 \pm 0.58$ $\mathrm{mg} / \mathrm{l}, 3.64 \pm 0.71 \mathrm{mg} / \mathrm{l}$ and $2.03 \pm 0.28 \mathrm{mg} / \mathrm{l} \mathrm{in}$ April, May and June respectively (Table 2). In Ganga river water $\mathrm{PO}_{4}^{3-}$ values ranged between 3.56 to $5.79 \mathrm{mg} / \mathrm{l}$ [26]. Sultana et al. [27] found the $\mathrm{PO}_{4}^{3-}$ concentration from $0.28 \mathrm{mg} / \mathrm{l}$ to $4 \mathrm{mg} / \mathrm{l}$ of the Turagriver. Present study exceeded the permissible limit of phosphate in fresh water according to WHO guideline [28].

In this study the observed mean sulfate values at different months of Dhaleshwaririver were $6.61 \pm 1.78 \mathrm{mg} / \mathrm{l}, 7.61 \pm 2.16 \mathrm{mg} / \mathrm{l}$ and $3.68 \pm 0.23 \mathrm{mg} / \mathrm{l} \mathrm{re}$ spectively (Table 2). Moniruzzaman et al. [29] studied the anion concentration in water of Burigangariver, Bangladesh and $\mathrm{SO}_{4}^{2-}$ concentration were ranged from 2.0 to $9.8 \mathrm{mg} / \mathrm{l}$. Sulfate concentration found very low comparing with the permissible limit (22 $\mathrm{mg} / \mathrm{l})$ according to DoE [30].

Nitrate $\left(\mathrm{NO}_{3}^{-}\right)$concentration in water samples varied from $0.51 \mathrm{mg} / \mathrm{l}$ at St-1 in June to $3.66 \mathrm{mg} / \mathrm{l}$ at St-3 in April in our present study. Mean value $2.55 \pm 1.35$ $\mathrm{mg} / \mathrm{l}$ was found in April, again mean value $2.38 \pm 1.02 \mathrm{mg} / \mathrm{l}$ in May and $0.78 \pm$ $0.25 \mathrm{mg} / \mathrm{l}$ was in June were found respectively (Table 2). Sultana et al. [27] found the nitrate concentration from 0.6 to $3.5 \mathrm{mg} / \mathrm{l}$ of the Turag river, Bangladesh. Concentration of basic anion of $\mathrm{NO}_{3}^{-}$were varied from 12.9 to $34.5 \mathrm{mg} / \mathrm{l}$ 
Md. K. H. Real et al.

Table 2. Anionic concentration in the water samples of Dhalehwari river.

\begin{tabular}{|c|c|c|c|c|c|c|c|}
\hline Month & Sampling station & $\begin{array}{l}\mathrm{PO}_{4}^{3-} \\
(\mathrm{mg} / \mathrm{l})\end{array}$ & Mean \pm SD & $\begin{array}{l}\mathrm{SO}_{4}^{2-} \\
(\mathrm{mg} / \mathrm{l})\end{array}$ & Mean \pm SD & $\begin{array}{c}\mathrm{NO}_{3}^{-} \\
(\mathrm{mg} / \mathrm{l})\end{array}$ & Mean \pm SD \\
\hline \multirow{3}{*}{ April } & St-1 & 3.53 & & 4.63 & & 1.0 & \\
\hline & St-2 & 3.71 & $3.29 \pm 0.6$ & 7.11 & $6.61 \pm 1.8$ & 2.94 & $2.55 \pm 1.4$ \\
\hline & St-3 & 2.63 & & 8.1 & & 3.66 & \\
\hline \multirow{3}{*}{ May } & St-1 & 3.0 & & 5.2 & & 1.79 & \\
\hline & St-2 & 4.4 & $3.64 \pm 0.7$ & 8.25 & $7.61 \pm 2.2$ & 1.79 & $2.38 \pm 1.0$ \\
\hline & St-3 & 3.51 & & 9.37 & & 3.55 & \\
\hline \multirow{3}{*}{ June } & St-1 & 2.1 & & 3.44 & & 0.51 & \\
\hline & St-2 & 2.31 & $2.03 \pm 0.3$ & 3.9 & $3.68 \pm 0.2$ & 1.0 & $0.78 \pm 0.25$ \\
\hline & St-3 & 1.74 & & 3.69 & & 0.82 & \\
\hline
\end{tabular}

in Buriganga river Bangladesh recorded by Moniruzzaman et al. [29]. The nitrate concentration of Dhaleshwari River was within the permissible limit (10.0 $\mathrm{mg} / \mathrm{l})$ throughout the study period according to DoE Bangladesh [30].

\subsection{Correlation Matrix among Different Bacteriological, Physiochemical and Anion Concentration of Dhaleshwari River Water}

Correlation matrix among the parameters determined by Karl Pearson's correlation coefficient along with their significant test are given in the following table (Table 3). Present study showed that dissolved oxygen had significant positive correlation with $\mathrm{pH}(\mathrm{r}=0.797 ; \mathrm{p}<0.05) . \mathrm{PO}_{4}^{3-}$ showed significant positive relation with temperature $(\mathrm{r}=0.787 ; \mathrm{p}<0.05)$ and $\mathrm{SO}_{4}^{2-} \quad(\mathrm{r}=0.694 ; \mathrm{p}<0.05)$ again it showed significant strong negative relation with $E$. coli $(\mathrm{r}=-0.842 ; \mathrm{p}<$ $0.01)$ and $V$. cholerae $(\mathrm{r}=-0.789 ; \mathrm{p}<0.05)$. There seen significant strong positive relation between $\mathrm{NO}_{3}^{-}$and $\mathrm{SO}_{4}^{2-}(\mathrm{r}=0.890, \mathrm{p}<0.01)$ and significant negation relation between $\mathrm{NO}_{3}^{-}$and $V$. cholera $(\mathrm{r}=-0.699 ; \mathrm{p}<0.05)$.

There found decrease trend $(\mathrm{r}=-0.707 ; \mathrm{p}<0.05)$ in total coliform bacteria with the increase of DO and increase trend with the increase of temp $(r=0.755$; $\mathrm{p}<0.05)$. E. coli bacteria showed significant negative relation with temperature, $\mathrm{PO}_{4}^{3-}, \mathrm{SO}_{4}^{2-}$. Vibrio cholerae also showed significant strong positive relation with $E$. coli bacteria $(\mathrm{r}=0.956 ; \mathrm{p}<0.01)$ and significant negative relation with $\mathrm{pH}(\mathrm{r}=-0.833, \mathrm{p}<0.01)$. Environmental parameters such as temperature, salinity, $\mathrm{pH}$ and dissolved oxygen play a foremost part in the distribution of bacteria in aquatic environment [31]. Alam and Zafar [32] found a decreased trend in $E$. coli concentration with the increase of $\mathrm{pH}(\mathrm{y}=-5.0745 \mathrm{x}+65.599)$ and with the increase of DO $(y=-1.091 x+29.408)$ in water samples at Karnafuly river estuary Bangladesh which is similar to the present study.

\section{Conclusions}

The present study reveals that the bacteriological parameters investigated in river water were found above the permissible limits of WHO at different locations 
Table 3. Correlation matrix among the bacterial load, physicochemical parameters and the anion concentration of Dhaleshwari river.

\begin{tabular}{|c|c|c|c|c|c|c|c|c|c|c|}
\hline Parameters & $\mathrm{pH}$ & DO & Temp & BOD & $\mathrm{PO}_{4}^{3-}$ & $\mathrm{SO}_{4}^{2-}$ & $\mathrm{NO}_{3}^{-}$ & T. Coliform & E. coli & V. cholerae \\
\hline $\mathrm{pH}$ & 1 & & & & & & & & & \\
\hline DO & $0.797^{\star}$ & 1 & & & & & & & & \\
\hline Temp & 0.086 & -0.327 & 1 & & & & & & & \\
\hline BOD & -0.133 & -0.165 & 0.18 & 1 & & & & & & \\
\hline $\mathrm{PO}_{4}^{3-}$ & 0.493 & -0.041 & $0.787^{\star}$ & 0.051 & 1 & & & & & \\
\hline $\mathrm{SO}_{4}^{2-}$ & 0.464 & 0.196 & 0.664 & 0.388 & $0.694^{*}$ & 1 & & & & \\
\hline $\mathrm{NO}_{3}^{-}$ & 0.571 & 0.401 & 0.335 & 0.311 & 0.431 & $0.89^{\star *}$ & 1 & & & \\
\hline T. coliform & -0.518 & $-0.707^{\star}$ & $0.755^{\star}$ & 0.235 & 0.243 & 0.261 & -0.001 & 1 & & \\
\hline E. coli & -0.651 & -0.179 & $-0.776^{*}$ & -0.064 & $-0.841^{\star *}$ & $-0.762^{*}$ & -0.646 & -0.289 & 1 & \\
\hline V. cholerae & $-0.833^{\star *}$ & -0.427 & -0.597 & -0.061 & $-0.789^{\star}$ & $-0.748^{\star}$ & $-0.699^{*}$ & -0.016 & $0.956^{\star *}$ & 1 \\
\hline
\end{tabular}

${ }^{\star}$ Correlation is significant at the 0.05 level (2-tailed). ${ }^{*}$ Correlation is significant at the 0.01 level (2-tailed).

of Dhaleshwari river. The presence of coliform bacteria indicates that the water contaminated with fecal waste and hence the usage of the water could be hazardous to human health. As a result, the presence of high number of pathogenic bacteria in the river might create a severe injury to fish. Again ingestion of these bacteria during bathing and swimming in the river might cause or rather entrance of waterborne pathogens in food chain around the area. Low dissolved oxygen, higher BOD values, higher $\mathrm{pH}$ values reveals that the river water was polluted with organic and chemical pollutants. Considering the microbial and physicochemical pollution level of the water, it is suggested that the water is not suitable for human activities.

Negative relation among the high bacterial load and anion concentration reveals that there is potentiality of bioremediation of nutrients in the river water. In this regard future study on microbial load, abundance of microalgae, zooplankton, phytoplankton, fish abundance alone with different macro and micro nutrients content should be carried out for a longer period of time to get a clear idea on bacterial load and physicochemical parameters of Dhaleshwari river.

\section{References}

[1] Higgins, I.J. and Burns, R.G. (1975) The Chemistry and Microbiology of Pollution. Academic Press, London.

[2] Pelczar, M.J., Chan, E.C.S. and Krieg, N.R. (1988) Microbiology. McGraw-Hill, New York.

[3] Mead, A.M., Helm, G., Callan, P. and Atlas, R.M. (1999) A Prospective Study of Drinking Water Quality and Gastrointestinal Diseases. The New England Journal of Medicine, 245, 224-248.

[4] Okpokwasili, G.C. and Akujobi, T.C. (1996) Bacteriological Indicators of Tropical Water Quality. Environmental Toxicology Water Quality, 11, 77-81. https://doi.org/10.1002/(SICI)1098-2256(1996)11:2<77::AID-TOX1>3.0.CO;2-5

[5] Mara, D. (1978) Sewage Treatment in Hot Climates. John Wiley \& Sons, New York.

[6] Faruque, S.M., Naser, I.B., Islam, M.J., Faruque, A.S.G., Ghosh, A.N., Balakrish 
Nair, G., Sack, D.A. and Mekalanos, J.J. (2005) Seasonal Epidemics of Cholera Inversely Correlate with the Prevalence of Environmental Cholera Phages. Proceedings of the National Academy of Sciences of the United States of America, 102, 1702-1707. https://doi.org/10.1073/pnas.0408992102

[7] Haque, M.I. (2008) Water Resources Management in Bangladesh. Anushilan, Chuadanga and Dhaka.

[8] GoB-UNICEF (Government of Bangladesh-United Nations International Children's Emergency Fund) (1991) Rural Water Supply and Sanitation Program 1992-1999, Dhaka, Bangladesh.

[9] Majumder, R.C. (1971) History of Ancient Bengal. Tulsi Prokashani, Kolkata.

[10] Bangladesh Bureau of Statistics (2013) District Statistics 2011 Tangail. Ministry of Planning Government of People's Republic of Bangladesh.

[11] Brammer, H. (2002) Land Use and Land Use Planning in Bangladesh. University Press Limited, Dhaka.

[12] APHA (American Public Health Association) (1976) Standard Methods for Examination of Water and Waste Water. 14th Edition, American Public Health Association Inc., Washington DC.

[13] Alam, M. (2013) Microbial Species Diversity and Hydrological Effects on Their Occurrence at Karnaphuli River Estuary. Agricultural Science Research Journal, 3, 158-166.

[14] Banglapedia (2008) The National Encyclopedia of Bangladesh. Asiatic Society of Bangladesh, Dhaka, Bangladesh.

[15] Mihir, L.S., Mahbubar, R.K., Mohammad, A. and Sirajul, H. (2009) Banterial Load and Chemical Pollution Level of the Buriganga River, Dhaka, Bangladesh. Bangladesh Journal of Botany, 38, 87-91.

[16] Hasan, M.M., Ahmed, M.K., Hafiz, F., Hussain, A.M.I., Parveen, S. and Rahman, S. (2006) Load of Heterotrophic and Nitrifying Bacteria in the Sewage Lagoon and the Receiving River Buriganga. Bangladesh Journal Microbiology, 23, 93-97.

[17] Eukene Oporto-Bensig (2014) Fecal and Total Coliform Levels of Bhusian River, Philippines. International Journal of Engineering Science and Technology, 4, 76-82.

[18] Godfree, A.F., Kay, D. and Wyer, M.D. (1997) Faecal Streptococci as Indicators of Faecal Contamination in Water. Journal of Applied Microbiology, 83, 110-119. https://doi.org/10.1046/j.1365-2672.83.s1.12.x

[19] EPA (Environmental Protection Agency) (1984) Health Effects Criteria for Fresh Recreational Waters, EPA-600 I-84-004. Office of Water, USEPA, Washington DC. http://www.epa.gov/nerlcwww/frc.pdf

[20] Islam, M.S., Draser, B.S. and Sack, R.B. (1995) The Aquatic Environment as Reservoir of Vibrio cholerae: A Review. Journal Diarrhoeal Diseases Research, 11, 197206.

[21] Glass, R.I., Huq, M.I., Stoll, B.J., Khan, M.U., Merson, M.H., Lee, J.V. and Black R.E. (1982) Endemic Cholera in Rural Bangladesh. American Journal of Epidemiology, 116, 959-970. https://doi.org/10.1093/oxfordjournals.aje.a113498

[22] Alam, M., Sultana, M., Nair, G.B., Sack, R.B., Sack, D.A., Siddique, A.K., Ali, A., Huq, A. and Colwell, R.R. (2006) Toxigenic Vibrio cholerae in the Aquatic Environment of Mathbaria, Bangladesh. Applied Environmental Microbiology, 72, 28492855. https://doi.org/10.1128/AEM.72.4.2849-2855.2006

[23] Islam, M.S., Meghla, N.T., Suravi and Al Mamun, S. (2012) Status of Water Quality in the Dhaleshwari River and Its Effect on Aquatic Organism. Journal of Environmental Science and Water Resources, 1, 192-201. 
[24] Das, B. (1997) Fisheries Resources Management in Bangladesh. Bangla Academy, 153-155.

[25] Khondker, M. and Abed, S.G. (2013) Seasonality of Phytoplankton Productivity of the river Turagof Dhaka in Relation to Its Water Quality. Bangladesh Journal of Botany, 42, 287-294.

[26] Mishra, A., Mukherjee, A. and Tripathi, B.D. (2009) Seasonal and Temporal Variations in Physicochemical and Bacteriological Characteristics of River Ganga in Varanasi. International Journal of Environmental Research, 3, 395-402.

[27] Sultana, R., Rahman, M.M. and Mia, M.Y. (2014) Heavy Metal Concentration in the Lesser Spiny Eel (Macrognathus aculeatus) of the Turag River, Bangladesh. University Journal of Zoology (Rajshahi University), 33, 01-08.

[28] WHO (World Health Organization) (2011) Guidelines for Drinking Water Quality-1, Recommendation. 4th Edition, World Health Organization, Geneva.

[29] Moniruzzaman, M., Elahi, S.F. and Jahangir, M.A.A. (2009) Study on Temporal Variation of Physicochemical Parameters of Buriganga River Water through GIS (Geographical Information System) Technology. Bangladesh Journal of Scientific and Industrial Research, 44, 327-334.

[30] DoE (Department of Environment) (1997) Environmental Quality Standard for Bangladesh. Ministry of Environment and Forestry, Dhaka, Bangladesh.

[31] Palaniappan, R. (1982) Studies on the Microflora of the Prawn Penaeus indicus, Milne Edwards (Crustacea, Decopodes, Penaedae) with Reference to Its Digestive System. PhD Thesis, Annamalai University, India.

[32] Alam, M.W. and Zafar, M. (2013) Spatial and Temporal Variation of Escherichia coli in Water and Soil with Relation to Water Parameters at the Estuary of Karnafuly River, Bangladesh. African Journal Bacteriological Research, 5, 1-18. https://doi.org/10.5897/JBR12.026

\section{Submit or recommend next manuscript to SCIRP and we will provide best service for you:}

Accepting pre-submission inquiries through Email, Facebook, LinkedIn, Twitter, etc. A wide selection of journals (inclusive of 9 subjects, more than 200 journals)

Providing 24-hour high-quality service

User-friendly online submission system

Fair and swift peer-review system

Efficient typesetting and proofreading procedure

Display of the result of downloads and visits, as well as the number of cited articles

Maximum dissemination of your research work

Submit your manuscript at: http://papersubmission.scirp.org/

Or contact aim@scirp.org 